\title{
Cytological diagnosis of metastatic melanoma presenting as an isolated pleural effusion: A case report
}

\author{
Konstantinos Kosmas*1 ${ }^{*}$, Anna Tsonou ${ }^{1}$, Georgia Mitropoulou ${ }^{2}$, Anastasia Mandilara ${ }^{1}$, Olga Papadopoulou ${ }^{1}$, Eufrosyni \\ Salemi ${ }^{1}$ \\ ${ }^{1}$ Department of Cytopathology, General Chest Diseases Hospital of Athens "SOTIRIA", Greece \\ ${ }^{2}$ Pathology Department, "Agia Sofia" Children's Hospital, Athens, Greece
}

Received: February 19, 2018

DOI: $10.5430 /$ jst.v8n2p7

\author{
Accepted: April 8, 2018 \\ Online Published: April 24, 2018 \\ URL: http://dx.doi.org/10.5430/jst.v8n2p7
}

\begin{abstract}
Malignant melanoma (MM) is a malignant melanocytic neoplasm that occurs mainly in the skin but it can also involve any tissue. It has the capacity to metastasize widely and quickly to various sites without any intermediate stops, sometimes many years after treatment of the primary tumor. It is almost impossible to predict which organ system will be invaded by melanoma from a given primary site. We report the cytomorphologic and immunocytochemical findings of a male patient with isolated pleural metastasis of MM without pulmonary parenchymal metastatic involvement after 10 years of progression-free survival. Pleural fluid cytology revealed epithelioid cells of variable sizes and configuration isolated or in clusters with abnormal hyperchromatic nuclei, irregularly-shaped nucleoli, abundant eosinophilic cytoplasm, multinucleated giant cells, intranuclear cytoplamic inclusions as well as many cytoplasmic melanin pigmented tumor cells. Immunocytochemical markers for melanoma HMB-45 and S-100 were positive. Metastasis of MM to pleural fluid is rare and diagnosing the disease by cytology is challenging and requires medical expertise as well as knowledge of clinical context and immunocytochemical staining evaluation.
\end{abstract}

Key Words: Malignant pleural effusion, Malignant melanoma, Cytology, HMB-45, S-100

\section{INTRODUCTION}

Worldwide, approximately 232,100 new cases $(120,600$ men and 111,500 women) of MM are diagnosed each year and an estimated 55,500 deaths (31,400 men and 24,100 women) with almost two of three deaths occurring in more developed regions (21,300 men and 15,000 women). ${ }^{[1]}$ Melanoma can affect persons of all ages (especially the elderly) including infants (extremely rare) and young individuals with mean age at diagnosis of $\sim 50$ years. ${ }^{[2]}$ It has the capacity to metastasize widely and quickly to various sites, with metastases to skin, subcutaneous tissues and regional lymph nodes being more common than visceral organs and other sites. ${ }^{[3,4]}$ It is almost impossible to predict which organ system will be invaded by melanoma from a given primary site. ${ }^{[3]}$ However, accurate diagnosis of the initial site of recurrence is an important predictor of survival. ${ }^{[5]}$ Non visceral metastases are related to longer survival rates. Metastases to various viscera have been known to occur without any intermediate stops, sometimes many years after treatment of the primary tumor. ${ }^{[4]}$ Although metastases of MM to the lung are relatively common, ${ }^{[6-14]}$

\footnotetext{
*Correspondence: Konstantinos Kosmas; Email: kosmas_konstantinos@yahoo.gr; Address: Konstantinos Kosmas, 152 Mesogion Av., 115 27
} Athens, Greece. 
metastases to the pleura without pulmonary parenchymal metastatic involvement are extremely rare. ${ }^{[6-8,10-17]}$

This paper reports the cytomorphologic and immunocytochemical findings of a male patient with a history of MM who presented with isolated pleural metastasis without pulmonary parenchymal metastatic involvement after 10 years of progression-free survival.

\section{Case presentation}

The research was approved by the Ethical Review Committee of National and Kapodistrian University of Athens, Health Sciences.

A 76-year-old Caucasian man was admitted to the Emergency Department of General Chest Diseases Hospital of Athens "SOTIRIA" in August 2017 due to right anterior chest pain over the previous 5 days, progressive dyspnea and productive cough associated with the pain, fever, loss of appetite and weight loss over a period of 2 months. The patient had a history of stage III MM of the scalp with metastases to left cervical lymph nodes at the time of diagnosis, treated by surgical resection, lymphadenectomy and chemotherapy (cisplatin, dacarbazine and interferon $\alpha 2$ b) in September 2007. The patient responded well to the treatment and in September 2015 the last computed tomography scan of the brain, chest and abdomen as well as the total body bone scintigraphy were normal. In August 2017 and during his presence in our hospital, physical examination revealed decreased breath sounds and dullness to percussion in the right lung. A thorough skin and scalp examination did not reveal any suspicious lesion. The routine laboratory studies showed leukocytosis and other minor alterations with no specific diagnostic value. A chest $\mathrm{X}$-ray was performed which revealed a right-sided pleural effusion, followed by computed tomography scan of the chest which confirmed the right-sided pleural effusion. Abdominal ultrasound was negative for any suspected lesions. Considering that the patient had cervical lymph node metastasis at the time of diagnosis of his primary scalp melanoma, the pleural effusion could be the expression of a new site of metastasis. The patient underwent a right-sided thoracentesis. Due to worsening dyspnea and fatigue the patient was intubated and was placed on mechanical ventilation. However, his medical condition rapidly declined and he ultimately succumbed to death before performing any further laboratory or imaging investigations or before initiation of any therapy.

\section{Results}

Pleural fluid cytology revealed diffuse epithelioid cells of variable sizes and configuration isolated or in clusters with eccentrically located large clearly abnormal hyperchromatic nuclei, prominent, large, irregularly-shaped nucleoli as well as abundant eosinophilic cytoplasm (see Figure 1). There have also been observed few large intranuclear cytoplamic inclusions (see Figure 2) as well as many bi-, tri-, and multinucleated giant cells. The presence of many cytoplasmic melanin pigmented tumor cells was suggestive of melanoma. The diagnosis was confirmed by positive staining of tumor cells with antibodies against HMB-45 (Immunologic, HMB45 clone, dilution 1:100) (see Figure 3) and S-100 (Thermo Fisher Scientific, 4C4.9 clone, dilution 1:100) (see Figure 4).

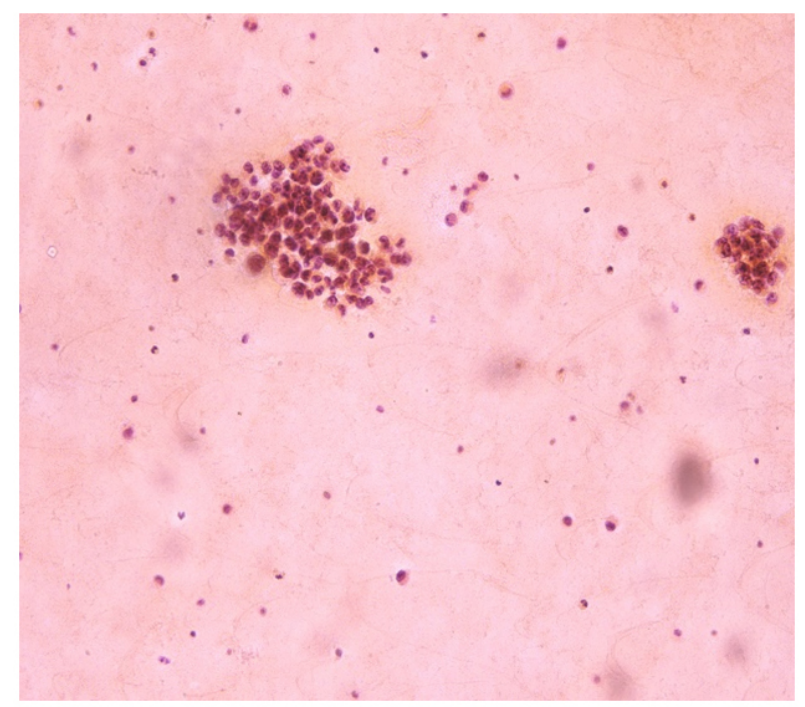

Figure 1. Epithelioid cells of variable sizes and configuration isolated or in clusters. Papanicolaou $\times 20$

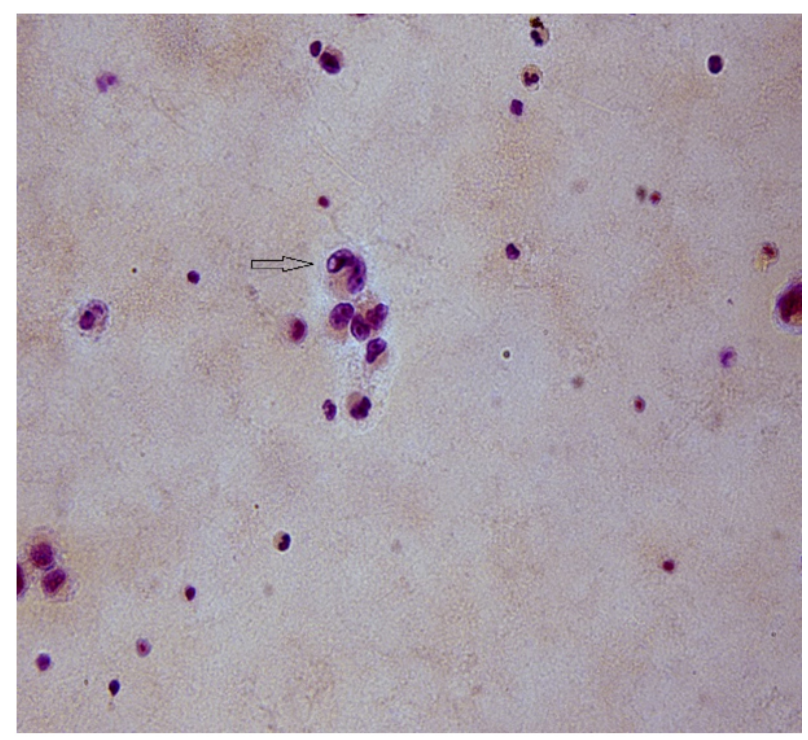

Figure 2. Epithelioid cell with intranuclear cytoplamic inclusion (arrow). Papanicolaou $\times 40$ 


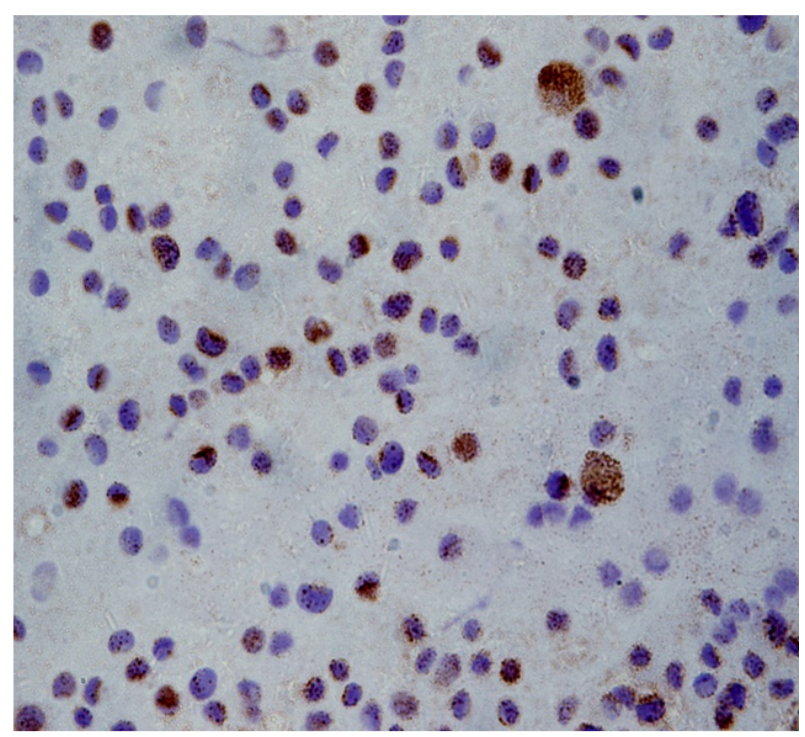

Figure 3. Immunocytochemical staining (cytoplasmic) for HMB-45 was positive. HMB- $45 \times 40$

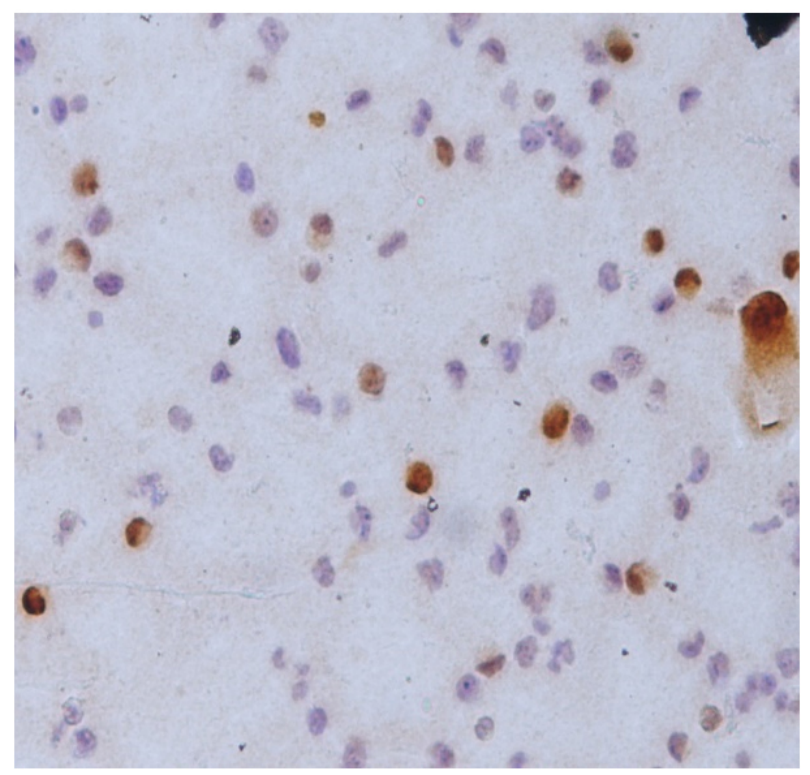

Figure 4. Immunocytochemical staining. (nucleus and cytoplasmic) for $\mathrm{S}-100$ was positive. $\mathrm{S}-100 \times 20$

\section{Discussion}

Metastases of MM to the pleura without pulmonary parenchymal metastatic involvement are rare. To the best of our knowledge, only a few reports of MM occurring as an isolated pleural effusion have been published since it is not unlikely that the limited number of cases reported in the literature is a reflection of the fact that many cases are never reported. A literature review was performed and revealed 14 articles from 1978 to 2017, reporting a total of only 16 cases of pleural effusions due to MM occurring without lung parenchymal disease (see Table 1).

Published by Sciedu Press
Chen T. James et al. in a study of 130 patients with MM and thoracic complications, pleural effusions were seen in 20 patients. In seven patients, pleural effusion was associated with adenopathy and in 10 patients with multiple pulmonary nodules. An isolated effusion was seen in only three patients $(2 \%) .{ }^{[6]}$ A case of MM presenting as an isolated pleural effusion was reported by Ferdinando de Vita et al., ${ }^{[7]}$ Akansha Chhabra et al., ${ }^{[9]}$ Kartik Anand et al., ${ }^{[10]}$ Luckraz Heyman et al., ${ }^{[14]}$ Sotelo D. Andre et al. ${ }^{[15]}$ and another case by Kiser C. Andy et al. ${ }^{[18]}$ In these published cases, there was no melanocytic lesion at the time of presentation and the pleural MM appeared to be of metastatic origin. In the remaining 7 cases, there was an apparent primary pleural melanoma. ${ }^{[8,11-13,16,17,19]}$

Malignant pleural effusions signify advanced systemic disease and are associated with a low survival rate and diminished quality of life. Eggermont M. Alexander reported that patients with metastatic melanoma have a median survival time of 8-9 months and an estimated 3-year survival rate of less than $15 \% .{ }^{[20]}$ Song Xue et al., reported that patients at stage IIIB/IIIC had a median overall survival of 24.3 months, with a survival rate of $67.2 \%$ at 1 year, $42.9 \%$ at 2 years, and $32.1 \%$ at 3 years. ${ }^{[21]}$

The incidence of melanoma is increasing due to its unresponsiveness to currently available chemotherapeutic drugs such as dacarbazine and carmustine. ${ }^{[22]}$ However, recent clinical exploitation of BRAF oncogene addiction and immune checkpoint inhibitors in advanced melanoma has revolutionized the treatment of metastatic melanoma patients. ${ }^{[22,23]}$ The drugs developed through these approaches have advanced patient care by improving overall survival, as well as quality of life. BRAF and MEK inhibition and CLTA-4 blockade have established an entirely new standard of care in the last years. Targeted kinase inhibition and immune checkpoint blockade have different strengths and weaknesses. Kinase inhibitors generally have rapid and impressive response rates but modest progression-free survival while immunotherapy can achieve durable tumor control, but is often associated with lower response rates and slower time to clinical benefit. ${ }^{[23]}$

It is important to note that, in the case of Sotelo D. Andre et al. even in a patient 14 years status post primary lesion resection, there were no distant metastases and the patient didn't receive chemotherapy. In the case reported by Luckraz Heyman et al.,the patient was 10 years post resection of the primary lesion, there was no lymphatic extension, and the lesion was less than $1 \mathrm{~mm}$ in depth. Finally, in the case reported by Kartik Anand et al., the patient was thought to be early stage (stage IA) when a malignant pleural effusion was discovered. 
Table 1. Literature Review (1978-2017) of Metastatic Malignant Melanoma to the Pleura

\begin{tabular}{|c|c|c|c|c|c|c|c|c|}
\hline Authors & Year & $\begin{array}{l}\text { Number of } \\
\text { patients }\end{array}$ & Age & Sex & $\begin{array}{l}\text { History of } \\
\text { malignant } \\
\text { melanoma }\end{array}$ & $\begin{array}{l}\text { Primary location of } \\
\text { malignant melanoma }\end{array}$ & $\begin{array}{l}\text { Immunochemical } \\
\text { markers }\end{array}$ & $\begin{array}{l}\text { Age of diagnosis of } \\
\text { malignant melanoma }\end{array}$ \\
\hline $\begin{array}{l}\text { Chen JT. } \\
\text { et al. }\end{array}$ & 1981 & $20(3 / 17)^{*}$ & N/A & N/A & Yes & N/A & - & N/A \\
\hline $\begin{array}{l}\text { Shameem } \\
\text { M. et al. }\end{array}$ & 2011 & 1 & 46 & M & No & - & $\begin{array}{l}\text { HMB-45 (+), S-100 (+) } \\
\text { (in pleural fluid } \\
\text { specimens) }\end{array}$ & 46 \\
\hline $\begin{array}{l}\text { Sotelo } \\
\text { AD. et al. }\end{array}$ & 2003 & 1 & 37 & M & Yes & Scalp & - & 23 \\
\hline $\begin{array}{l}\text { Luckraz } \\
\text { H. et al. }\end{array}$ & 2005 & 1 & 64 & F & Yes & Right upper arm & $\begin{array}{l}\text { HMB-45 (+), S-100 (+) } \\
\text { (in histological } \\
\text { specimens of pleural } \\
\text { lesion) }\end{array}$ & 54 \\
\hline $\begin{array}{l}\text { Anand K. } \\
\text { et al. }\end{array}$ & 2017 & 1 & 65 & $\mathrm{~F}$ & Yes & Left shoulder & $\begin{array}{l}\text { HMB-45 (+), S-100 (+) } \\
\text { (in histological } \\
\text { specimens of pleural } \\
\text { lesion) }\end{array}$ & 49 \\
\hline $\begin{array}{l}\text { Chhabra } \\
\text { A. et al. }\end{array}$ & 2015 & 1 & 74 & M & Yes & $\begin{array}{l}\text { Thoracic cutaneous } \\
\text { melanoma }\end{array}$ & - & N/A \\
\hline $\begin{array}{l}\text { Smith S. } \\
\text { et al. }\end{array}$ & 1978 & 1 & 49 & M & No & - & - & 49 \\
\hline $\begin{array}{l}\text { Ohata Y. } \\
\text { et al }\end{array}$ & 2009 & 1 & 49 & M & No & - & $\begin{array}{l}\text { HMB-45 (Focally +) } \\
\text { S-100 }(+) \\
\text { (in histological } \\
\text { specimens of pleural } \\
\text { lesion) }\end{array}$ & 49 \\
\hline $\begin{array}{l}\text { Kiser } \\
\text { AC. et al. }\end{array}$ & 2002 & 1 & 51 & M & Yes & Left chest wall & - & 48 \\
\hline $\begin{array}{l}\text { De Vita } \\
\text { F. et al. }\end{array}$ & 2011 & 1 & 70 & F & Yes & Right forearm & - & 65 \\
\hline $\begin{array}{l}\text { Cheng L. } \\
\text { et al. }\end{array}$ & 2014 & 1 & 36 & F & No & - & $\begin{array}{l}\text { Melan-A (+), S-100 (+) } \\
\text { (in histological } \\
\text { specimens of pleural } \\
\text { lesion) }\end{array}$ & 36 \\
\hline $\begin{array}{l}\text { Um SW. } \\
\text { et al. }\end{array}$ & 2003 & 1 & 61 & M & No & - & $\begin{array}{l}\text { HMB-45 (+), S-100 (+) } \\
\text { (in histological } \\
\text { specimens of pleural } \\
\text { lesion) }\end{array}$ & 61 \\
\hline $\begin{array}{l}\text { Wang Q. } \\
\text { et al. }\end{array}$ & 2015 & 1 & 36 & F & No & - & $\begin{array}{l}\text { Melan-A (+), S-100 (+) } \\
\text { HMB-45 (+), Vim }(+) \\
\text { (in histological } \\
\text { specimens of pleural } \\
\text { lesion) }\end{array}$ & 36 \\
\hline $\begin{array}{l}\text { H. HAJA } \\
\text { MYDIN } \\
\text { et al. }\end{array}$ & 2013 & 1 & 29 & M & No & - & $\begin{array}{l}\text { Melan-A (+), HMB-45 } \\
(+) \\
\text { (in histological } \\
\text { specimens of pleural } \\
\text { lesion) }\end{array}$ & 29 \\
\hline
\end{tabular}

*In 3 patients the effusion was isolated and unilateral.

In contrast to our patient, in those cases there were no distant in the literature as primary pleural mesothelioma probably metastases and they all were MMs of early stages. Most dis- reflect pleural metastasis of an occult primary melanoma tant metastases from melanoma become evident clinically or are detected during follow-up visits within a few years after treatment of the primary tumor. In addition, cases presented elsewhere (probably cutaneous) since pleural mesothelioma shares certain clinical and imaging characteristics with pleural melanoma, ${ }^{[16]}$ or a late metastasis of a previously removed 
lesion that might have been forgotten, or might have been misdiagnosed melanoma. However, it is important to remember that late metastases ( $>10$ years, sometimes even over 25 years after excision of the primary tumor) are not uncommon in this neoplasm. ${ }^{[24]}$ In our patient with stage III MM, isolated pleural metastasis was noted 10 years after treatment of primary tumor.

The time elapsed between the surgical resection and the onset of metastasis can be explained by the perception of tumor dormancy, according to which metastases often occur many years after the diagnosis and treatment of the primary tumor. It has been suggested that the underlying mechanism for this occurrence is prolonged persistence of tumor cells in a dormant state, probably due to the absence of sufficient growth signaling or inhibition by tissue factors, or control by the host immune response. ${ }^{[25]}$ Another possible explanation of late recurrence could be that a small portion of tumor cells could have a potential for metastasis, and in individuals with a subsequent recurrence, these cells could have been dormant for years before becoming evident. ${ }^{[26]}$ Mastrangelo J. Michael et al. believe that there is a connection to the immune system of the host. There could be a loss of antin- genic manifestation altering the tumor immunogenicity or of the immune system of the host, therefore causing the late metastasis ${ }^{[27]}$ and Reintgan S. Douglas et al. that immunological factors could also cause a second primary metacronic tumor, and this would recede spontaneously leaving only the metastatic disease. This can be observed in $5 \%$ of the cases of metastatic melanoma. ${ }^{[28]}$

\section{Conclusion}

In conclusion, metastatic melanoma presenting with isolated pleural effusion in the absence of pulmonary parenchymal involvement is uncommon with only a few cases reported in the literature. In our case, a stage III melanoma patient appeared with late melanoma recurrence ten years after the initial diagnosis and treatment. The diagnosis by cytology only was challenging and required medical expertise, knowledge of clinical context and immunocytochemical staining evaluation.

\section{CONFLicts OF INTEREST Disclosure}

The authors declare that there is no conflict of interest statement.

\section{REFERENCES}

[1] Ferlay J, Soerjomataram I, Dikshit R, et al. Cancer incidence and mortality worldwide: sources, methods and major patterns in GLOBOCAN2012. Int J Cancer. 2015 Mar; 136: E359-86. PMid:25220842.

[2] Humphrey PA, Dehner LP, Pfeifer JD. The Washington Manual of Surgical Pathology. 2nd ed. Lippincott Williams \& Wilkins; 2012. $619 \mathrm{p}$.

[3] Lee YT. Malignant melanoma: pattern of metastasis. CA Cancer J Clin. 1980 May-Jun; 30: 137-42. PMid:6769552. https: //doi.org/10.3322/canjclin.30.3.137

[4] Koss LG (ed). Diagnostic Cytology and its Histopathologic Bases. 5th ed. Philadelphia, USA: Lippincott Williams \& Wilkins; 2005. $1295 \mathrm{p}$.

[5] Barnhill RL, Piepkorn M, Busam KJ. The Pathology of Melanocytic Nevi and Malignant Melanoma. 2nd ed. New York: Springer; 2004. $358 \mathrm{p}$.

[6] Chen JT, Dahmash NS, Ravin CE, et al. Metastatic melanoma in the thorax: report of 130 patients. AJR Am J Roentgenol. 1981 Aug; 137(2): 293-8. PMid:6789636.

[7] De Vita F, Giordano G, Fabozzi A, et al. Metastatic melanoma: an unusual presentation. Tumori. 2011 Jan-Feb; 97(1): 130-2. PMid:21528678.

[8] Shameem M, Akhtar J, Baneen U, et al. Malignant melanoma presenting as an isolated pleural effusion. Monaldi Arch Chest Dis. 2011 Jun; 75(2): 138-40. PMid:21932700.

[9] Chhabra A, Mukherjee V, Chowdhary M, et al. Black Pleural Effusion: A Unique Presentation of Metastatic Melanoma. Case Rep Oncol. 2015 May; 8(2): 222-5. PMid:26078741. https ://doi .or $\mathrm{g} / 10.1159 / 000430907$

Published by Sciedu Press
[10] Anand K, Cingam S, Peddi P. Recurrent Malignant Melanoma Presenting as Isolated Pleural Metastases in a Patient with Chronic Lymphocytic Leukemia. Case Rep Oncol. 2017 Jan; 10(1): 86-90. PMid:28203169. https://doi.org/10.1159/000455827

[11] Haja Mydin H, Currie GP, Denison AR, et al. A rare cause of pleural disease. QJM. 2013 Jun; 106(6): 571-2. PMid:23487832.

[12] Ohata Y, Haga T, Ogata S, et al. Malignant amelanotic melanoma of the pleura without primary skin lesion: an autopsy case report. Acta Med Okayama. 2009 Dec; 63(6): 379-84. PMid:20035295.

[13] Um SW, Yoo CG, Lee CT, et al. Apparent primary pleural melanoma: case report and literature review. Respir Med. 2003 May; 97(5): 5867. PMid:12735679. https://doi.org/10.1053/rmed.2003.14 82

[14] Luckraz H, Morgan M, Gibbs AR, et al. Pseudomesothelioma resulting from metastatic malignant melanoma. Eur J Cardiothorac Surg. 2005 Oct; 28(4): 655-6. PMid:16125958. https://doi .org/10.1 016/j.ejcts. 2005.05 .032

[15] Sotelo AD, Cicenia J, Tietjen PA. Recurrent Melanoma Presenting as Pleural Metastases Fourteen Years After Initial Cutaneous Presentation. Chest. 2003 Oct; 124: 288s-9s. https://doi.org/10.137 8/chest.124.4_MeetingAbstracts.288S-a

[16] Wang Q, Chen J, Dassarath M, et al. Primary malignant melanoma of the pleura with rapid progression: A case report and literature review. Oncol Lett. 2015 Jun; 9(6): 2713-5. PMid:26137133. https://doi.org/10.3892/ol.2015.3104

[17] Cheng L, Nie J, Li J, et al. Primary pleural malignant melanoma with rapid progression. Ann Thorac Surg. 2014 Jul; 98(1): 334-6. PMid:24996719. https://doi.org/10.1016/j.athoracsur.2 013.09 .065 
[18] Kiser AC, Egan TM. Metastatic melanoma to the pleural space. Ann Thorac Surg. 2002 Oct; 74(4): 1257. https ://doi.org/10.101 6/S0003-4975(01)03519-6

[19] Smith S, Opipari MI. Primary pleural melanoma. A first reported case and literature review. J Thorac Cardiovasc Surg. 1978 Jun; 75(6): 827-31. PMid:661351.

[20] Eggermont AM. Advances in systemic treatment of melanoma. Ann Oncol. 2010 Oct; 21 Suppl 7: vii339-44. PMid:20943639.

[21] Song X, Zhao Z, Barber B, et al. Overall survival in patients with metastatic melanoma. Curr Med Res Opin. 2015 May; 31(5): 987-91. PMid:25708472.

[22] Mahoney KM, Freeman GJ, McDermott DF. The Next ImmuneCheckpoint Inhibitors: PD-1/ PD-L1 Blockade in Melanoma. Clin Ther. 2015; 37: 764-82. PMid:25823918. https ://doi .org/10.1 016/j.clinthera.2015.02.018

[23] Luke JJ, Ott PA. Kinase inhibitors and immune check-point blockade for the treatment of metastatic melanoma and advanced cancer: synergistic or antagonistic? Expert Opin Pharmacother. 2013 Dec; 14(18): 2457-62. PMid:24138302. https://doi.org/10.1517/ 14656566.2013 .849244
[24] Cribier B, Asch PH, Regnier C, et al. Expression of human hair keratin basic 1 in pilomatrixoma. A study of 128 cases. Br J Dermatol. 1999 Apr; 140(4): 600-4. PMid:10233308. https ://doi.org/10 $.1046 / j .1365-2133.1999 .02757 . x$

[25] Lopez M, Giacomini P, Carpano S. Melanoma. Oncologia medica pratica, Società Editrice Universo, Roma, 2005. 1565-96 pp.

[26] Koh HK, Sober AJ, Fitzpatrick TB. Late recurrence (beyond ten years) of cutaneous malignant melanoma. Report of two cases and a review of the literature. JAMA. 1984 Apr; 251(14): 185962. PMid:6700088. https://doi.org/10.1001/jama.1984.03 340380041020

[27] Mastrangelo MJ, Bellet RE, Berd D. Immunology and Immunotherapy on human cutaneous malignant melanoma. In: Clark WH, Goladman LI, Matrangleo MJ, eds. Human Maligant Melanoma, New York, Grune \& Stratton Inc., 1979. 355-416 pp.

[28] Reintgen DS, McCarty KS, Woodard B, et al. Metastatic malignant melanoma with an unknown primary. Surg Gynecol Obstet. 1983 Mar; 156(3): 335-40. PMid:6828979. 